\title{
EVALUATION OF HUMAN RELIABILITY IN SELECTED ACTIVITIES IN THE RAILWAY INDUSTRY
}

\author{
Erika SUJOVÁ, Helena ČIERNA \\ Technical University in Zvolen \\ Michał MOLENDA \\ Silesian University of Technology
}

\begin{abstract}
:
The article focuses on evaluation of human reliability in the human - machine system in the railway industry. Based on a survey of a train dispatcher and of selected activities, we have identified risk factors affecting the dispatcher's work and the evaluated risk level of their influence on the reliability and safety of preformed activities. The research took place at the authors' work place between 2012-2013. A survey method was used. With its help, authors were able to identify selected work activities of train dispatcher's risk factors that affect his/her work and the evaluated seriousness of its influence on the reliability and safety of performed activities. Amongst the most important finding fall expressions of unclear and complicated internal regulations and work processes, a feeling of being overworked, fear for one's safety at small, insufficiently protected stations.
\end{abstract}

Key words: Human Reliability, Human Error, Performance Influencing Factors, Survey

\section{INTRODUCTION}

Human error is inevitable and reducing accidents and minimising the consequences of accidents that do occur is best achieved by learning from errors, rather than by attributing blame. Feeding information from accidents, errors and near misses into design solutions and management systems can drastically reduce the chances of future accidents. Hence, studying human error can be a very powerful tool for preventing disaster [1]. Due to the effect of many factors, it is very important to express the values of probability of a mistake caused by a human. However, it can be very easily identified which factors affect a person's performance (PIF), one type of mistake can be affected the most. The critical role assigned to HF in design and safety assessment depends on the widespread use of automation and its impact on human errors. Automation improves performance of routine operations, aims at reducing workload, and sucessully limits most human blunders at behavioural level. However, automation introduces a variety of safety critical issues due to 'errors' of cognition, which are particularly correlated and strongly affected by socio-technical contextual conditions, e.g. training and experience, physical working environment, teamwork, etc. [2].

Reliability of human factors is understood as an inseparable part of risk evaluation. Many authors deal with the method of human reliability evaluation $[3,4,5]$. Evaluation of human reliability or errors is a very important process that requires fundamental knowledge of the system that is of objects, equipment, identification of risks, work activities and mainly individuals'characteristics - employees. The term „human error "sounds very simple, however, it had not been clearly identified for a long time. In 1990 human error was defined as a generally used expression, which included all incidents within a planned chain of mental of physical actions that do not lead to achieving planned results, while these errors cannot be affected by other accidental effects. As a result, an error occurs when a goal or a required result is not achieved and this is a deviation from the required state. Bogdanovská [6] classifies two groups of human errors: errors caused by omission and execution errors. The first group consists of human errors that results from lack of attention, for example from forgetting, from not noticing a signal, etc. The second group is characterized by activities that are incorrectly performed, either in the wrong order, too early or too late, on a too small a scale, in the wrong direction, and other.

The presented research focuses on identification and evaluation of potential human factor errors in the humanmachine system in the railway industry. The research took place at the authors 'work place between 2012-2013. A survey method was used. With its help, authors were able to identify selected work activities of train dispatcher's risk factors that affect his/her work and the evaluated seriousness of its influence on the reliability and safety of performed activities.

\section{RISK FACTORS AFFECTING HUMANS IN A WORK PROCESS}

In the assessment of risks, the three components of the triangle above should be considered. People, organisation and technology have to be viewed as a whole, not as three independent part of the risk analysis (Fig. 1). They are plenty of interactions between the three concepts [1].

Risks that cause danger technological process in production and in services as well as risks that cause transporta- 
tion vehicles and transportation equipment to break down, are not only dependent on the technical state of machines and equipment, but are also dependent on human factors. We can state that a given system fully exhibits relationships of a basic model of a relationship with a human factor, of a technical instrument, and of the environment in which the evaluated process is taking place.

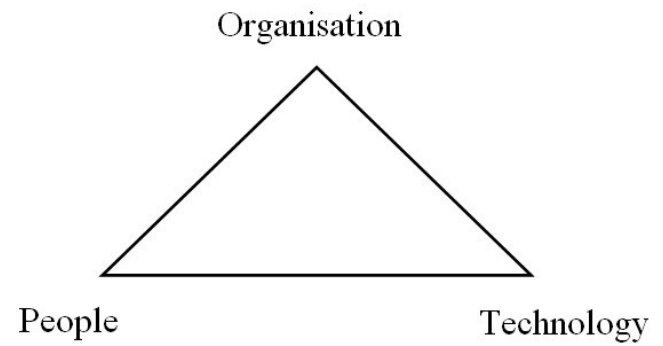

Fig. 1 People - Organisation - Technlogy Triangel

Figure 2 shows the interaction between humans and machines. In order to have a given task done, both elements are indispensable. Besides very few craftsmen or artists, no one can pretend working without the help of machines. On the other side, machines do not have intuition and intelligence abilities. They need orders like setup, start and (emergency-) stop operations. The human worker gets feedback from the machine: control parameters, alarms and other data. Only humans can understand these machine data, work them out, analyse them and transform them to new machine inputs. Humans are not ready to live in a fully automated society. The full automated airliners that Airbus tried to develop were refused by the consumers. Who would sit in plane without pilot? We see at that point, that fully automated systems are not yet possible. Interaction between human and machine will always exist. Both machines and humans are subject to errors and influence the quality of a product. The way risk is assessed for machines and humans is very different. Automated processes - done by machines - are exposed to few external influences, which are known and can be controlled. A machine delivers statistical data [1].

Risks occur in all aspects of a social life, in natural environments as well as in technical processes. From a general point of view and depending on reliability on the origin, risks can be divided into two groups:

- dependent on human activities - anthropogenic risk,

- risks not dependent of human activities - natural risks.
Anthropogenic risks are connected to human activities in the process of creating optimal conditions for life. Humans are constantly adjusting natural conditions according to their needs and expectations to create an optimal living environment. These activities, however, often a direct hazard to nature, are connected to an array of risks, which can be a source of such hazard. One group of anthropogenic risks consists of sociogenic risks. These are tied to social phenomena, to behavior of an individual who has a personality and has individuality. They do however depend on the following:

- quality of work of an individual,

- people's ability to communicate amongst themselves,

- effectiveness of management of work teams,

- working conditions created for employees, and

- level of quality of services provided to customers.

In practice, the most common is a combination of anthropogenic risks. In production and in services it is predominantly a combination of technogenic and sociogenic risks. Combined risks are a lot more dangerous than pure antrhopogenic risks and the probability that a risk will occur as a result is very high. On the other hand, is a more complicated process to lower these risks and risk prevention. It is demanding both on material and human resources [7].

Human organisms can be burdened in a work process by many forms of workloads, which can be characterized as a combination of two of its basic burdens - physical burden and psychological burden. Physical burden is in the legislation defined based on available values of physiological factors of burden at work: energy release and heart frequency, it is quantitatively defined. Our research focused on physical burden, which is an important factor that affects a person in their work activity and which greatly affects a person's reliability. Psychological burden of an employee is his/her internal interpretation of difficulty of tasks, also stress from work. Effects from the outside environment (including working environment) are demonstrated in behavior, in activities of physical functions and processes and can be responsible for a state called burden - stress or astate, which can a trigger a mechanism to develop a psychosomatic illness, professional illness. Stress in our times represents a real threat [8]. Broken social and physiological relationships at workplace in the form of not constructive disagreements between individuals naturally lead to such damaged behavior at work, which can cause an accident or an injury.

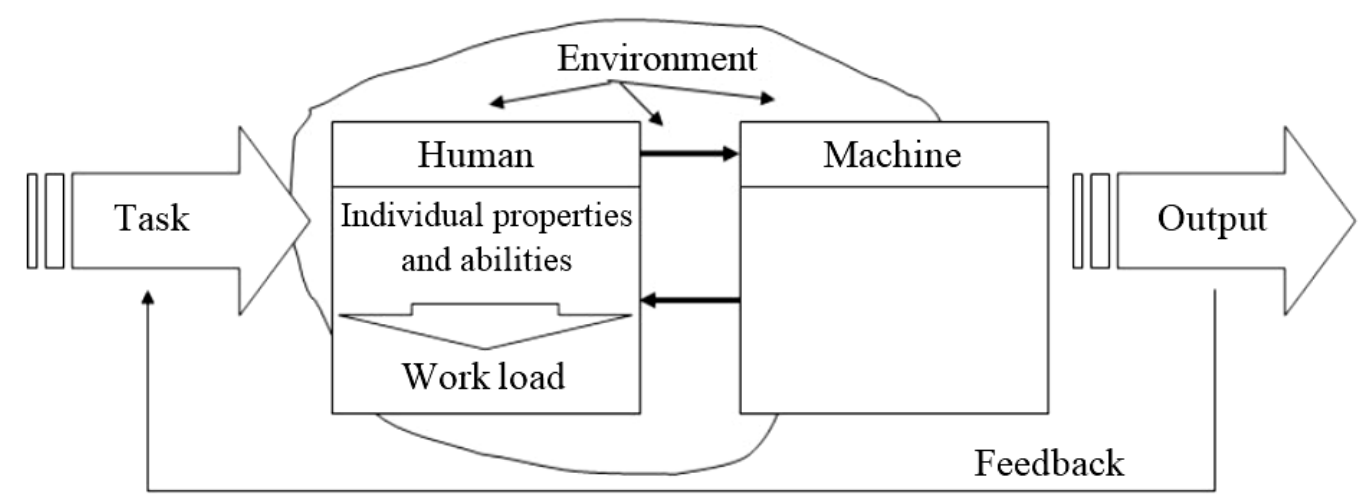

Fig. 2 Interactions between human and machine in envitonment 
Psychological burden is a factor that weighs on an organism that requires physical activity, psychological engagement with requirement and stimuli from the environment. We differentiate three forms of psychological burdens: sensory, mental and emotional. Sensory burden stems from demands to perform an activity by organs with peripheral capabilities and their structures of the central nervous system. This includes eye strain and hearing strain. Mental burden is a result of demands to process information that demand physical functions and psychological processes, such as attention, imagination, use of memory, thinking and decision making. Emotional burden results from demands that cause a response [9].

Characteristics of work and of work environment evaluated based on psychological burden at work are:

- infrequent work load or work under time pressure,

- internal temperature at workplace,

- how monotonous work is,

- noise level or other factors distracting groups I and II at work,

- social interaction,

- material and organizational responsibility,

- risk of one's health or life threat of other persons,

- shift work, overtime or night shift,

- non-standard work environment, and

- physical comfort.

The basic starting point when evaluating psychological burden is not only the fact that actual work can be a factor for a given person (employee), but also that work can be optimal for the employee's education and motivation. However, it is performed in unfavorable conditions, under unfavorable conditions which burden a given person [8].

\section{RESEARCH METHOD}

\section{Analysis of Work Activities and Characteristics of a Posi- tion "Train Dispatcher"}

Transportation infrastructure and technology used in various kinds of transportation are a source of hazards that need to be thoroughly analyzed and we need to find ways how to eliminate them. Transportation technologies are defined by norms and internal regulations. A considerable problem is adherence to these, including using resources for safe work environment and using prescribed protection resources. It is necessary to create an efficient control mechanism, as a basic tool to decrease risks [7].

When studying transportation systems and the role that humans play in them, it is necessary to start with a general analysis of a system, which includes the following:

- administrative analysis that allows setting of employee's responsibilities at a specific place of work, division of roles within a system,

- technological analysis, that determines behavior at work from a chronological point and working studies,

- psychological analysis that sets in place a structure of abilities and mental capacity for a person's reliable performance,

- ergonomic analysis, which is based on analysis of physical, biological and psycho-sociological working conditions, including analysis of a work regime and rest as well as analysis of machines and technical equipment in transportation systems and from a psycho-physiological demands on employees when using these [10].
In our research we focused on psychological analysis, that is, evaluation of risk factors that affect work and reliability of humans in terms of the selected profession in activities of railway transportation. We evaluated a position of train dispatcher, which in the analyzed field represents a high responsibility and high risk position. A dispatcher controls and manages railway traffic at a given train station or at a given section of a railway track. This position has high demands on adaptability, short term memory, accuracy, precision, ability to take responsibility, to divide attention, to use a wide eye angle, to distinguish colors and shades of colors, to be alert, to remain balanced, to have good spacial vision, to concentrate, to visualize processes and foresee events, to think, to be flexible, self-control, self-discipline, independence, decision-making, resistance to sensory burdens, organization skills, self assurance, ability to act promptly, ability to be social, ability to adapt eye sight to light and darkness, to distinguish sound intervals, long term memory, constructive and spacial imagination, and practical thinking [11].

Methodology of Evaluation of Reliability of Work Activities of a Dispatcher

The aim of the analysis was to identify possible errors of employees during their work activities that can potentially affect safety and frequency of railway transportation and to evaluate factors that can influence their performance at work.

Before performing an analysis, it was necessary to fully understand work organization and all processes and working activities of a dispatcher. We have studied technical and documented materials about equipment and technology, as well as the company's organizational and technical regulations, written directives, norms and safety requirements, statistical data about accidents and injuries.

From this information we have created a list of potentially hazardous activities, indicating errors that can occur during regular activities as well as in emergency situations and we have identified factors that potentially lead to these errors.

The next step was to add to each identified hazard a threat. It was necessary to identify how a dangerous event can occur, that is, how could material value and human lives be at risk.

We have determined existence of risk factors and consequently their existence based on a survey method. The survey aimed to find and evaluate factors that affect a reliable or unreliable performance of a human. These were negative factors of work and work environment. We evaluated work organization and social environment at the workplace [11].

Based on evaluation of the survey we have entered factors that affect safe and reliable performance of dispatchers and evaluation of PIF (Performance Influencing Factors) [2]. In Table 1. we divided affects of PIF based on productivity, comfort and reliability into three levels: minimal, significant or key.

\section{Methodology of Creating a Survey}

Based on primary collection of information, analysis of evaluated work activities (Table 1) and study of internal regulations, we have set goals and determined main questions for the survey. The aim was to find out, actually to confirm, presence of risk factors such as stress, inattentiveness and not adhering to regulations and technology. 
Table 1

Evaluation of Work Activities of a Dispatcher Related to Development of Human Errors and Factor PIF

\begin{tabular}{|c|c|c|c|c|}
\hline $\begin{array}{l}\text { A list of potentially } \\
\text { hazardous activities } \\
\text { of a dispatcher }\end{array}$ & $\begin{array}{l}\text { Possible negative } \\
\text { consequences when } \\
\text { a part breaks down }\end{array}$ & $\begin{array}{c}\text { Human } \\
\text { Error }\end{array}$ & $\begin{array}{l}\text { Influencing } \\
\text { Factors PIF }\end{array}$ & Factor PIF \\
\hline $\begin{array}{l}\text { Movement and other activities } \\
\text { caused by a train: } \\
\text {-incorrect organization of work } \\
\text { during moving, } \\
\text {-did not verify the level of damage } \\
\text { of a railroad switch, } \\
\text {-a train switch base that was not } \\
\text { removed, } \\
\text {-incorrect use of the railway break, } \\
\text { - incorrect process during move- } \\
\text { ment between train stations (PMD), } \\
\text {-incorrect request for a PMD. }\end{array}$ & $\begin{array}{l}\text { - cars move without } \\
\text { control: car derail- } \\
\text { ment, cars moving } \\
\text { into an occupied or } \\
\text { dead-end rail, colli- } \\
\text { sion of cars with } \\
\text { other motor vehicles } \\
\text { (rail) } \\
\text { - life threatening, } \\
\text { health hazard, mate- } \\
\text { rial damage and de- } \\
\text { layed trains. }\end{array}$ & $\begin{array}{l}\text { Insufficient } \\
\text { concentration } \\
\text { on work }\end{array}$ & $\begin{array}{l}\text { - demanding work in relation to how } \\
\text { complex performed activities are, } \\
\text { - decreased concentration, } \\
\text { - underestimation of situation, } \\
\text { - a person is overworked, } \\
\text { - in the summer, fatigue and de- } \\
\text { creased concentration due to higher } \\
\text { temperature, } \\
\text { - decreased concentration due to inap- } \\
\text { propriate extending of work period. }\end{array}$ & significant \\
\hline $\begin{array}{l}\text { Working with dangerous equip- } \\
\text { ment: } \\
\text {-putting a rail switch under (before) } \\
\text { a car, } \\
\text {-incorrectly build a displacement } \\
\text { road, } \\
\text {-not securing rail switches and } \\
\text { derailers, }\end{array}$ & $\begin{array}{l}\text { - cars move without } \\
\text { control: car derail- } \\
\text { ment, cars moving } \\
\text { into an occupied } \\
\text { or dead-end rail, } \\
\text { collision of cars with } \\
\text { other motor vehicles } \\
\text { (rail) }\end{array}$ & $\begin{array}{l}\text { Error } \\
\text { of judgment }\end{array}$ & $\begin{array}{l}\text { - wrong communication among em- } \\
\text { ployees } \\
\text { - unfavorable working environment } \\
\text { - misunderstandings, conflicts, } \\
\text { - insufficient cooperation between } \\
\text { organizational entities, } \\
\text { - very high intensity of information, } \\
\text { - decreased concentration. }\end{array}$ & significant \\
\hline $\begin{array}{l}\text {-incorrect (not approved) use } \\
\text { of station's safety equipment, } \\
\text { - incorrect (not approved) use } \\
\text { of railway safety equipment, } \\
\text {-not closing access road, } \\
\text {-incorrect use of safety equipment } \\
\text {-not patrolling access road } \\
\text {-not following indication of regimes } \\
\text { of safety equipment. }\end{array}$ & $\begin{array}{l}\text { - life threatening, } \\
\text { health hazard, mate- } \\
\text { rial damage and de- } \\
\text { layed trains. }\end{array}$ & Stress & $\begin{array}{l}\text { Little support of employees from man- } \\
\text { agement, } \\
\text { - insufficient amount of recognition } \\
\text { and not appreciating employees } \\
\text { - negative motivation, } \\
\text { - emotional fatigue, } \\
\text { - (feelings of helplessness, of depres- } \\
\text { sion, anger or animosity). }\end{array}$ & minimal \\
\hline $\begin{array}{l}\text { Managing railway traffic: } \\
\text {-incorrect approach when switching } \\
\text { to telephone communication, } \\
\text {-switching numbers of trains, } \\
\text {-not finding out (incorrectly deter- } \\
\text { mining) availability of a railway, } \\
\text {-incorrectly set access to other than } \\
\text { the determined rail, } \\
\text {-not checking correct placement } \\
\text { of rail switches and derailers, } \\
\text {-incorrect process during emergen- } \\
\text { cy stopping of a passing train, } \\
\text {-incorrect process during train de- } \\
\text { parture } \\
\text {-misunderstanding (incorrect un- } \\
\text { derstanding) of train personnel }\end{array}$ & $\begin{array}{l}\text { Train moving to an } \\
\text { incorrect rail. Cars } \\
\text { move without con- } \\
\text { trol: car derailment, } \\
\text { cars moving into } \\
\text { an occupied or dead- } \\
\text { end rail, collision } \\
\text { of cars with other } \\
\text { motor vehicles (rail) } \\
\text { - life threatening, } \\
\text { health hazard, mate- } \\
\text { rial damage and de- } \\
\text { layed trains. }\end{array}$ & $\begin{array}{l}\text { Inappropriate } \\
\text { division } \\
\text { of work }\end{array}$ & $\begin{array}{l}\text { - late preparation of supporting docu- } \\
\text { ments during planned emergencies, } \\
\text { - incomplete and incorrect infor- } \\
\text { mation, } \\
\text { - incorrect delegation of responsibility, } \\
\text { - not verifying accuracy of performed } \\
\text { tasks } \\
\text { time constraint, } \\
\text { - pressure to perform while sacrificing } \\
\text { safety, } \\
\text { - not following processes, cutting cor- } \\
\text { ners, } \\
\text { - underestimating a situation, } \\
\text { - no knowledge of regulations, } \\
\text { - insufficient motivation to work safely }\end{array}$ & key \\
\hline
\end{tabular}

The main question was to find out how much are dispatchers distracted by environmental factors, which take their attention from full attention while performing a task and what stops them from performing at $100 \%$. The basis for a successful survey is, besides determining a goal and main questions, formulation of a hypothesis. We worked with a hypothesis that a large number of dispatchers works under pressure because long term dispatchers are people who cannot find employment in other fields.

Before formulating individual questions, we determined the structure of the entire survey. Based on the theme and goals of the survey, we divided the survey into three parts. In the first part was introduction and reasons for the survey as well as identification information of respondents: sex, age, highest education achieved and years in the position of dispatcher. The second part focused on evaluation of external factors that affect dispatchers' activities (physical environmental factors and organizational factors). It consisted of 7 questions, and each included 3-5 clarifying multiple choice sub-questions (no, partially, sometimes, yes, etc.). The third part of the survey focused on evaluating internal factors and stressful factors. Respondents in this section expressed their impressions and feelings about work activities. In this part, questions aimed to evaluate physical and psychological difficulty of work, feeling of responsibility, questions about experiencing stress and tension, fear, etc. The final question in the section was an open question. Respondents could write suggestions to improve work or observations about what stops them from performing work without problems. 
We created the survey at www.iankety.sk, which helped us with creating a layout of the survey, collection and finally evaluation of the survey. We approached 105 employees from ŽSR (Railways of Slovak Republic) in the position of dispatcher, from various parts of Slovakia, from different categories of railway stations. To ensure anonymity, respondents received surveys electronically via email to their email accounts. Respondents could send their filled out survey online and results from responses were automatically summarized and statically evaluated [11].

\section{Survey Evaluationand Results}

A total of 81 respondents, 51 men and 30 women, age from 26 to 60 , with average age of 40.7 years, participated in the survey. Average of years worked as dispatcher was 19.

As part of evaluation, we are including questions and answers which yielded the most important results, which identified key and significant influences on occurrence of human error. Table 2 presents self-evaluation of dispatchers in the view work position responsibility in percentage of responses to sub-questions 1 and 2 .

Based on these answers, it is evidentthat a majority of dispatchers considers their work to be mentally demanding, where $90.1 \%$ from which $38.3 \%$ of respondents answered that they find their work mentally very demanding. A large majority of respondents feels that they have big responsibility for human lives and material value. Also $1.3 \%$ of respondents admitted a feeling of big responsibility as part of their worksometimes and $98.7 \%$ feels big responsibility always.

The following Table 3 presents the most serious findings of our research with information accessibility and regulation comprehensibility. Table contains questions and the percentage of respondents' answers to each answers options.Sub-question 3 and 4 focused on access to information and their timeliness. It dealt mainly with information regarding train trips, changes in regulation and providing rail transportation during planned activities. Results indicate that a majority (approx. $80 \%$ of respondents) is satisfied with their services. From answers to subquestions 5 and 6 , it is evident that due to complicated and unclear regulations approximatelly more then $70 \%$ of respondents has problem occur when employees try to follow them.In contrast, more than $30 \%$ of respondents perceive regulations as simple and easy to remember. It is evident from the results that in order to improve accessibility and intelligibility of regulations Slovak Railways should revise its internal guidelines.

Figure 3 shows the answers to the questions that we have tried to identify the causes of the feeling of stress, anxiety or stress at work dispatcher. For the evaluation of the area we chose 14 areas.

Table 2

Self-evaluation of dispatchers in the view work position responsibility

\begin{tabular}{lcccc}
\hline \multicolumn{1}{c}{$\begin{array}{c}\text { Evaluation of responses } \\
\text { to question }\end{array}$} & Not at all & Partially & Sometimes & Yes, very much \\
\cline { 2 - 5 } & & & $\%$ & \\
1. Is your work mentally demanding? & 2.5 & 7.5 & 51.9 & 38.2 \\
2. Does your position of dispatcher have a lot of responsibility? & 0 & 0 & 1.3 & 98.7 \\
\hline
\end{tabular}

Table 3

Evaluation of information accessibility and regulation comprehensibility

\begin{tabular}{|c|c|c|c|c|}
\hline Evaluation & Yes & Probably yes & Probably no & No \\
\hline of responses to question & \multicolumn{4}{|c|}{$\%$} \\
\hline $\begin{array}{l}\text { 3. Do you have access to all information that is necessary } \\
\text { for a successful performance of your work? }\end{array}$ & 21.0 & 61.8 & 13.6 & 3.8 \\
\hline $\begin{array}{l}\text { 4. Are you sufficiently and timely informed about necessary } \\
\text { information required for safe performance of your work? }\end{array}$ & 18.6 & 59.3 & 18.6 & 3.8 \\
\hline 5. Is regulation clearand can it be easily remembered? & 1.3 & 26.0 & 51.9 & 21.0 \\
\hline 6. It is easy to followthe prescribed regulation? & 2.5 & 29.7 & 50.7 & 17.3 \\
\hline
\end{tabular}

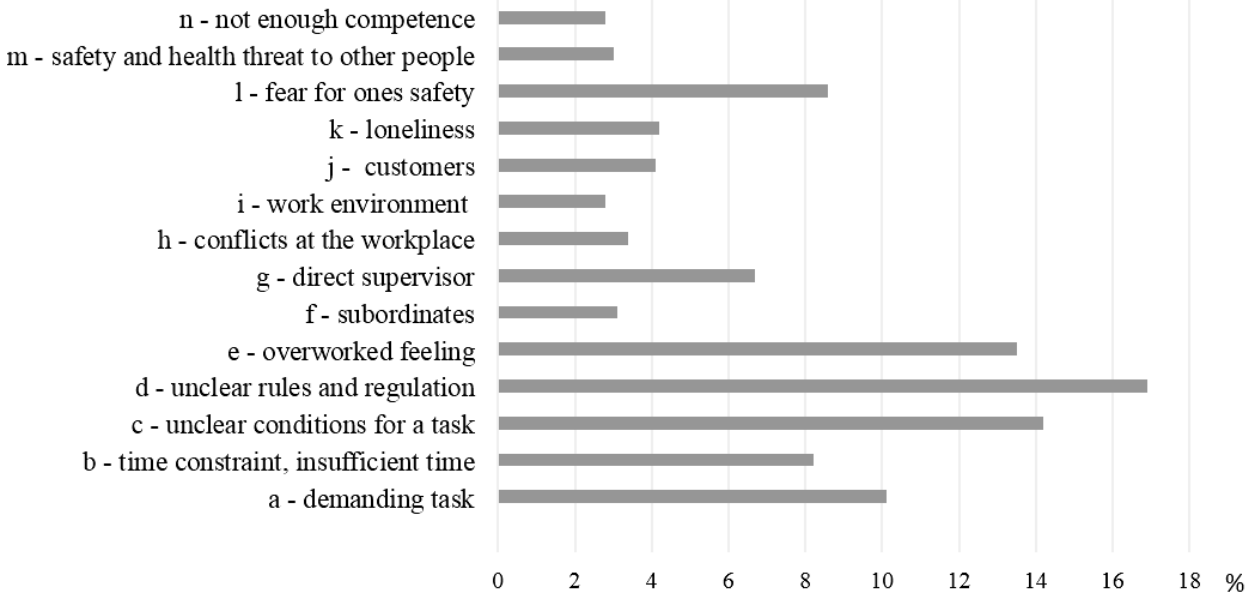

Fig. 3 Evaluation of the responses share of 14 evaluated areas of the question: Have you experienced or are you experiencing stress, a feeling of uneasiness, anxiety, fear, anger at work? What causes this? 
Based on the responses, it is evident that only $1.9 \%$ of respondents does not have uneasy feelings at work and does not feel stress. Following are stress factors organized from most from frequent to least frequent based on answers:

- $16.9 \%(d)$ - unclear rules and regulations,

- $14.2 \%$ (c) - unclear conditions for a task (not enough information, bad technological process, etc.)

- $13.5 \%$ (e) - feeling of being overworked (unexpected work, exceptionality, unexpected stream of information, etc.),

- $10.1 \%(a)$ - demanding task (not enough personnel),

- $8.6 \%$ (I) - fear for own safety,

- $8.2 \%$ (b) - time related stress, not enough time,

- $6.7 \%(\mathrm{~g})$ - direct supervisor,

- $4.1 \%(\mathrm{j})(\mathrm{k})$ - customers, loneliness,

- $3.4 \%(\mathrm{~h})$ - conflicts at work, colleagues,

- $3 \%$ and less - subordinates (f), fear safety and health of others (m), not enough competence (n), work environment (i).

\section{DISCUSSION}

By evaluating the survey, we have gained information about how specific factors affect performance and reliability of humans and which from the analyzed factors need to be improved in a given working system. We learned from evaluation of the survey that dispatchers perceive their position as sometimes very mentally demanding, with a lot of responsibility and according to some employees not sufficiently appreciated. Despite these negatives, close to half of respondents is satisfied with their current position.

Among our key finding are that dispatchers feel that unexpected work and insufficiently staffed work gives them a feeling of being overworked and they work under time stress. According to dispatchers, a very important fact is that prescribed regulation is not clear, it is hard to memorize and to follow hard in everyday work activities. This problem is perceived by $70 \%$ of respondents. To improve application of regulation in practice we suggest that employees performing the work be more involved in creation of such regulations.

Following are clarifications of most important finding and suggestions for improvement:

1. Regulation. As a main problem that causes stress at work, respondents indicated how complicated and unclear regulation is. We suggest updating the regulation especially the technical part and to evaluate unnecessary teaching and testing of knowledge of safety and other equipment, which employees do not work with and do not come in contact with because it leads to oversaturation by unnecessary information.

2. Overworking. Respondents identified overworking as one of the most important problems and they see that is occurs predominantly during unexpected work. We suggest to increase number of employees at stations and possibly resolve moments of unexpected rush with help from emergency employees.

3. Working alone - fear for one's safety. This problem affects employees at small stations where in majority of cases (during weekends and at night) they are the only working personnel at the station. They have no protection, they have no way of protecting themselves in case of an attack, and buildings are not equipped against intrusions. This is a serious problem and one solution could be to set up an alarm system connected to a local police station. Also, increasing a number of employees to a minimum of two or on the contrary implementing automated tasks where humans would only perform a safeguarding function.

4. Not enough competence. Dispatchers have a feeling that they have more tasks due to downsizing. On the other hand, they were taken competencies, which they would need to more effectively and faster provide transport during unexpected situations. This is mainly competence in relation to technical factors such as dealing with employees from other transport companies. This problem can be solved by changing organization and management of operations.

5. Technical equipment at work place. Dispatchers are missing connection with train conductors. In emergencies they do not have timely access to important information so as to get help, to inform other groups, or to ensure work at the station (connecting trains, turnover trains) and so that they can safely and quickly bring in a broken down train from the rails to the station. In this case, the use of a walkie-talkie might be a solution.

6. Superiors. Subordinates are missing recognition and positive feedback for their work. They are not sufficiently motivated and recognized and from their superiors they mainly receive negative motivation in the form of sanctions and cut in bonuses in case of a problem. In this case, improvement is in the hands of direct supervisors. To improve working the environment, it necessary to positively stimulate and motive their subordinates.

\section{CONCLUSION}

We can say that human errors have an important influence on the quality of production processes. Human erroranalysis and subsequent risk reduction are of significant concern for all type of human processtasks found in various industries. By employing a systematic approach to this analysis, humanerror potential can be managed, its probability reduced and risk controlled.Transport in comparison with other areas of national economy takes place under specific conditions. Special requirements are imposed on the entire transport system even though the determining factor is quality of performance of human operators. As a results of failure of a subject in a transportation system are accidents followed by material and economic losses, health hazards or loss of life. Therefore, unreliability of transportation systems, caused by human error, despite technical advances is still very current.

In our research, we focused on identifying factors, which can potentially lead to human error during activities of a dispatcher at a train station. We conducted a survey research, which showed how specific factors affect performance and reliability of humans and which from the analyzed factors in the given working system need improvement. Amongst the most important finding fall expressions of unclear and complicated internal regulations and work processes, a feeling of being overworked, fear for one's safety at small, insufficiently protected stations.

Finally, we can conclude that a long existence of railway transportation (and with it accidents) various efficient control mechanisms have been put into place and practice that lead to a multitude of control functions. When human error occurs, when it is caused by an employee in the chain of transportation, a dispatcher, derailer or conductor, tragic 
consequences follow. Therefore, it is imperative to dedicate attention to these functions and analyze possible errors and failures, which was also the purpose of our research.

\section{REFERENCES}

[1] B. Dayer. (2006). Consideration of Human Errors in Risk Management [Online]. Available: http:// citeseerx.ist.psu.edu/viewdoc/download? doi=10.1.1.87.3972\&rep=rep1\&type $=p d f$

[2] P.C. Cacciabue. „Evaluation of human factors and man -machine interaction problems in the safety of nuclear power plants", in Nuclear Engineering and Design, vol. 109(3), November 1988, pp. 417-431.

[3] I. Tureková and Z. Turňová. „Assessment of human factor in production engineering", in Proc. of the 9th International Symposium on Occupational Safety and Hygiene, Guimaraes, Portugal, 2013, pp. 567-571.

[4] M. Schwarz, M. Dado and R. Hnilica. Rizikové faktory pracovného prostredia. Zvolen: TU Zvolen, 2013.

[5] L. Kotek et al. „Impact of microclimate conditions on the control room personnel - case study", in MM Science Journal, no. 3, October 2015, pp. 682-685.

\footnotetext{
Erika Sujová PhD, Doc. Helena Čierna PhD

Technical University in Zvolen, Faculty of Environmental and

Manufacturing Technology Department of Manufacturing

Technology and Quality Management

Studentska 26 Str. Zvolen 960 01, SLOVAKIA

e-mail: erika.sujova@tuzvo.sk cierna@tuzvo.sk

dr inż. Michał Molenda

Silesian University of Technology,

Faculty of Organization and Managemente

Institute of Production Engineering

Roosevelta 26 Str., 41-800 Zabrze, POLAND

e-mail: michal.molenda@polsl.pl
}

[6] G. Bogdanovská. (2007). Spol'ahlivost' l'udského faktora $\checkmark$ rámci systému manažérstva BOZP [Online]. Available: http://www.securityrevue.com/article/2007/12/ spolahlivost-ludskeho-faktora-v-ramci-systemumanazerstva-bozp/

[7] L. Šimák. (2006). Manažment rizík [Online]. Available: http://fsi.uniza.sk/kkm/files/publikacie/mn_rizik.pdf

[8] B.M. Zunk et al. "The Influence of Human Motivation Factors on the Successful Implementation of Product Life Cycle Management Tools: Explorative Findings and Managerial Implications", in Manufacturing Technology, vol. 13(4), pp. 580-586.

[9] Regulation No. 542/2007 of the Ministry of Health of the Slovak Republic on details of occupational health protection against physical stress, mental stress and sensory stress, 2007.

[10] M. Mayerová, O. Mikšík and V. Břicháček. Psychické zatižení a spolehlivost člověka v dopravě, Praha: NADAS, 1990.

[11] E. Krupová. „Posudzovanie rizika l'udskej chyby pri pracovných činnostiach v železničnej doprave", Bachelor thesis, Faculty of Environmental and Manufacturing Technology, Technical University in Zvolen, Zvolen, Slovak Republic, 2013. 